University of New Hampshire

University of New Hampshire Scholars' Repository

Sociology Scholarship

Sociology

$11-19-1991$

\title{
Who will leave? Oil, migration, and Scottish island youth
}

Carole L. Seyfrit

Old Dominion University

Lawrence C. Hamilton

University of New Hampshire, Durham, lawrence.hamilton@unh.edu

Follow this and additional works at: https://scholars.unh.edu/soc_facpub

Part of the Sociology Commons

\section{Comments}

This is an Author's Original Manuscript of an article published by Taylor \& Francis in Society \& Natural Resources in 1991, available online: https://dx.doi.org/10.1080/08941929209380791

\section{Recommended Citation}

Seyfrit, C.L. \& L.C. Hamilton. 1992. "Who will leave? Oil, migration, and Scottish island youth." Society and Natural Resources 5(3):263-276.

This Article is brought to you for free and open access by the Sociology at University of New Hampshire Scholars' Repository. It has been accepted for inclusion in Sociology Scholarship by an authorized administrator of University of New Hampshire Scholars' Repository. For more information, please contact Scholarly.Communication@unh.edu. 
AUTHORS' DRAFT. Final version published at:

Seyfrit, C.L. and L.C. Hamilton. 1992. "Who will leave? Oil, migration, and Scottish island youth."

Society and Natural Resources 5(3):263-276.

\title{
Who Will Leave? Oil, Migration, and Scottish Island Youth
}

Lawrence C. Hamilton

Carole L. Seyfrit

\begin{abstract}
Rural communities facing the prospect of rapid energy development consider tradeoffs between economic benefits and "way of life" disruption. One often-cited but unproven benefit of development is increased retention of local youth, who otherwise tend to migrate away. Using survey data from high school students of Scotland's Shetland and Orkney Islands (affected by North Sea oil development), we explore relations between intentions to migrate and individual background, aspirations, and attitudes. Attitudes towards oil development do not predict migration intentions. Instead, migration intentions are predicted by essentially the same variables identified in other studies, where energy development was not occurring. Thus, we found no evidence that oil development fundamentally changed young people's thoughts about leaving.
\end{abstract}

\section{INTRODUCTION}

Migration can produce rapid changes in society, culture, and population composition (Goldstein, 1976). This especially applies to rural areas, which may be sapped by outmigration or overwhelmed by newcomers as their perceived attractiveness shifts. Rural migration issues have gained recent salience in the context of large-scale energy developments and similar resource-extraction operations. Many rural communities historically experienced net outmigration, as young people left to live elsewhere. Energy development threatens the opposite problem, fast population growth fueled by new workers who stay while the boom lasts. Contemplating a proposed development, local residents may worry about the consequences of rapid growth. Their concern is balanced by a more benign proposition: that development will reduce young people's inclination to leave. Though unproven, this "beneficial retention hypothesis" (see Seyfrit 1986) is often assumed to be true, becoming a strong argument in favor of development (Andrews and Bauder, 1968; Dixon, 1978; Murdock and Leistritz, 1979; Ray, 1980; Summers, 1976).

In this paper, we examine survey data from high school students on Scotland's Shetland and Orkney Islands, sites of major North Sea oil developments. The students' migration plans provide one line of evidence for evaluating the beneficial retention hypothesis.

\section{REVIEW}

The proposition that job opportunities from industrial development will help rural communities retain their young people assumes that these young people want and can get the newly created jobs. Otherwise, the new jobs will go to newcomers while local youth continue to leave. Thus, the locals' migration intentions are an important focus of demographic research (see Bohlen and Wakeley 1950; Morrison 1975:241). Social psychological studies of attitudes and behavior often find that behavioral intentions predict behavioral outcomes (Fishbein 1978; Fishbein and Ajzen 1975; Hill 1981; Shuman and Johnson 1976). Lansing and Mueller (1967) demonstrated that migration intentions predict migration one year later.

Migration studies have often focused on community characteristics, but theoretical arguments also emphasize the importance of individuals' backgrounds and decision-making. Ritchey (1976) reviewed numerous social-demographic studies of migration. Basic findings include:

1. Young adults are the group most likely to migrate.

2. Migration rates increase with socioeconomic status. Education has more influence than occupation or income.

3. Kinship and friendship affiliations tend to tie individuals to communities.

Life cycle, knowledge and aspirations, economic opportunities, and social psychological factors help explain these empirical findings. As Lee (1966; cited in Kammeyer 1975:193) notes:

There are many personal factors which affect individual thresholds and facilitate or retard migration. Some of these are more or less constant throughout the life of the 
individual, while others are associated with stages in the life cycle and in particular with

the sharp breaks that denote passage from one stage to another.

Similarly, Mangalam and Schwarzweller (1970) emphasize the importance of individual aspirations and attitudes in determining who migrates.

Although migration studies consistently find that those moving tend to be young (Jansen, 1970), relatively few studies have looked specifically at predictors of youthful migration. Some of these concentrate on community-wide variables like employment rates, median income, public services, or other amenities including climate and recreation (e.g. Heaton, Clifford and Fuguitt, 1981; Murdock et al., 1984).

Studies of rural migration in a context of rapid resource development (energy or mining) have focused mainly on comparisons between communities. Freudenburg (1984) reported that high school students in a rapidly growing Colorado community were more likely than students in three comparison communities to say they planned to move away. Seyfrit (1986) found no significant differences between Utah counties with and without rapid growth in resource extraction industries. About $70 \%$ of the surveyed high school students from both types of area intended to leave. These results offer no support for the proposition that resource development in general reduces young peoples' outmigration. Seyfrit and Patterson (1990a) compared migration intentions of students on the Shetland and Orkney islands. Shetlanders were less likely to expect migration, which the authors attribute to differing local development strategies. Perhaps well-planned development has a better chance of slowing outmigration.

Gramling and Brabant (1986) argue that oil development, especially offshore oil development, does not follow the same boom-bust pattern seen in western U.S. mining communities. Oil and gas developments typically have a longer period of production and become tied to fluctuations in the world petroleum market. Developments onshore in support of the offshore industry are far more diverse than when a single industry or company locates in a rural area.

North Sea oil development in Shetland and Orkney provides an interesting case study for examining effects on the migration/retention of rural youth. The development certainly brought a wide spectrum of new jobs at all levels of skill. Occupational opportunities ranged from engineering, management, and medicine to maintenance, transportation, and education. However, the development began during times of very low unemployment (2.2\% in Shetland 1973-74) — so predevelopment outmigration could not be driven solely by lack of jobs.

If oil development and associated opportunity improvements had a substantial effect on Shetland/Orkney youth, we might expect to find their pattern of migration intentions different from that widely reported elsewhere, among communities not experiencing oil development. ${ }^{1}$ In this paper, we use survey data on Shetland/Orkney high schoolers to explore the question, Who will leave? Comparing our results with those of previous studies provides a preliminary basis for evaluating arguments about the unique effects of oil development on youth migration.

\section{HISTORY}

Large oil fields were discovered under the North Sea in 1971. Subsequently, oil companies participating in development concluded that Shetland and Orkney, Scottish island groups about 100 miles apart and 100 miles from the oil, would be good terminal sites for pipelines from offshore rigs.

Terminals were eventually built on both islands; Shetland's Sullom Voe Terminal became the largest in Europe.

Soon after the announcement of oil discoveries, local councils in both Shetland and Orkney began efforts to control any onshore activity likely to disrupt the Islanders' "way of life" (Zetland County Council, 1973; Moira and Moira, 1973). They obtained Provisional Orders from the British Parliament, giving the councils unprecedented rights over construction of the oil terminals (Orkney County Council Act 1974; Zetland County Council Act 1974). These efforts aimed to minimize negative social impacts and maximize benefits from oil development (Seyfrit, 1989; Seyfrit, James, and Patterson, 1989; Seyfrit and Patterson, 1990b). Their apparent success contrasts with experiences of many other rural communities affected by rapid energy development.

The North Sea oil boom reversed decades of population decline on the islands. During the period from North Sea oil discoveries (1971) to completion of Sullom Voe Terminal (1982), Shetland's population increased by 33\%, not counting temporary workers (Figure 1; data from Shetland Islands Council, 1989). After 1982, however, Shetland's population fluctuated and slightly declined. 
The population boom seen in Figure 1 reflected both increased migration of outsiders to Shetland, and decreased migration of Shetlanders away (Figure 2). Both trends eventually reversed, so that after 1981 net migration again became negative. Lower outmigration over 1975-1979 briefly supports the development-reduces-loss proposition, but the permanence of this reduction appears questionable. From these data we cannot know who was moving or why; in particular, we have little direct information about the retention of local youth.

\section{$<<$ Figure 2 about here $>>$}

Below we describe findings from a survey of Shetland and Orkney high school students, conducted during the spring of 1988. Out of 1,404 students enrolled in forms S3-S6, 796 questionnaires were returned, 781 of which form the basis for this analysis (remainder unused due to missing data). ${ }^{2}$ School administrators cooperated with the survey, and questionnaires were administered by classroom teachers. We have no indication that respondents differ systematically from nonrespondents, except for an overrepresentation of younger (S3) students from both Shetland and Orkney.

\section{WHO INTENDS TO LEAVE?}

Table 1 lists variables for this analysis. The dependent variable, leaving, is a dummy coded 1 for respondents expecting to live most of the rest of their lives away from the Shetland and Orkney Islands. Of the 781 respondents, 245 (31.4\%) expected to leave. (For brevity, we will often shorten "most likely to spend remainder of life elsewhere" to "leaving" or a similar term. Survey responses reflect migration intentions rather than actual migration, though.)

\section{$<<$ Table 1 about here $>>$}

Other items in Table 1 include background, aspirations, and attitudes towards the islands and oil development. Both attitude scales are composites, discussed later (Tables 3 and 4).

Fifty-seven percent of the respondents lived in the Orkney Islands, and the remainder in Shetland. Shetlanders were significantly less likely to intend migration (Table 2 ): $25.4 \%$ versus $35.8 \%$ of the Orcadians. Figures 3 and 4 display further bivariate findings. The proportion of leavers:

1. increases with age, especially contrasting 16-18 year olds with younger students;

2. is unrelated to gender;

3. is more than twice as high among those born off-island;

4. is significantly lower for children of long-term (over 30 years) residents;

5. increases if father holds a professional or technical job;

6. doubles among those aspiring to university or college education; and

7. is higher among those aspiring to professional/technigal jobs after finishing their education. Except for gender, these differences are significant at $\alpha=.001$ ( $\chi^{2}$ ests).

$$
\begin{aligned}
& <<\text { Table } 2 \text { about here }>> \\
& <<\text { Figure } 3 \text { about here }>> \\
& <<\text { Figure } 4 \text { about here }>>
\end{aligned}
$$

\section{ATTITUDES TOWARDS ISLANDS AND OIL}

Table 3 lists 14 items assessing attitudes towards family and community. Some ask about general satisfaction, others question family closeness or feelings of fitting in. We earlier saw variables reflecting nativity: being island-born and having parents who are long-term residents. Items in Table 3 tap social integration.

$$
<<\text { Table } 3 \text { about here }>>
$$

The Table 3 items together form our first attitude composite variable, named ties. Loadings on the first principal component, are given with each item. Component scores provide an optimal (maximum variance) composite variable, summarizing social ties to the islands as a single dimension. ${ }^{3}$ We found no significant differences between islands, and no island by leaving interaction, with respect to ties ( $F$ tests).

Table 4 lists eleven items reflecting attitudes towards oil development. As with Table 3, we form an optimal composite variable by calculating scores on the first principal component. The signs of the loadings lead to interpretation of this component as an anti-oil attitudes dimension. Antioil scores are unrelated to island or to likelihood of leaving ( $F$ tests).

\section{$<<$ Table 4 about here $>>$}




\section{PREDICTING "LIKELY TO LEAVE"}

Table 5 contains parameter estimates from logit regressions of leaving on the background, aspiration, and attitude variables listed in Table 1. The first column gives estimates and standard errors from a full model including ten predictors. Although the model fits well, several coefficients are indistinguishable from zero. At right in Table 5 are estimates from a reduced model, obtained by dropping predictors until only those with nonzero coefficients remain:

$$
\begin{aligned}
\mathrm{L}=\quad & -.442-.733 \text { shetland }-.754 \text { bornhere }-.409 \text { longterm }+.463 \text { fathprof } \\
& +.996 \text { college }-.620 \text { ties }
\end{aligned}
$$

where

$$
\mathrm{L}=\quad \log _{\mathrm{e}} \frac{\mathrm{P}(\text { leaving }=1)}{1-\mathrm{P}(\text { leaving }=1)}
$$

This more parsimonious model ([1], at right in Table 5) predicts leaving almost as well as the full model. It also makes fuller use of the data; dropping four unhelpful predictors regains more than 80 cases. $^{4}$

$$
<<\text { Table } 5 \text { about here }>>
$$

Variables with nonsignificant effects are female, age, wantprof, and antioil. Gender's nonsignificant effect comes as no surprise; Figure 4 shows little difference in proportions of boys and girls intending to leave. Age, on the other hand, exhibits a bivariate correlation (see Figure 3) that fades after adjustment for other predictors. Likewise the effect of wanting a professional/technical job (wantprof) weakens when we adjust for college aspirations (college) and father's job (fathprof).

The negligible impact of attitudes towards oil (antioil) was unexpected. Evidently, the disruption or promise of the oil industry does not loom large in these young peoples' plans about leaving or staying.

The other attitude variable, social ties to island (ties), does have a substantial impact. The coefficient on ties, -.620 , indicates that predicted odds of leaving decrease by about $46 \%$ with each standard deviation increase in ties.

Respondents aspiring to higher education $($ college $=1)$, or with professional/technical fathers (fathprof $=1$ ), are more likely to leave. The findings suggest that the Shetland and Orkney Islands, like many rural areas, are drained by outmigration of bright and ambitious youth. (Note also the positive, albeit nonsignificant, coefficient on wantprof.)

Table 2 showed Orcadians more likely to leave. This pattern becomes even stronger when we control for other variables. At any given levels of other variables in the reduced model of Table 5, Orcadians' odds of leaving are more than twice the Shetlanders' odds of leaving. Some of the interisland difference may reflect different planning strategies of the Shetland and Orkney governments. Shetland sought to diversify its employment base to include new entrepreneurial markets, in addition to the oil industry and traditional occupations. Orkney, in contrast, focused on preserving traditional industry more than expanding occupational opportunities (Seyfrit and Patterson, 1990a). Apart from the basic difference in rates, the predictors of leaving show similar effects when Shetland and Orkney respondents are analyzed separately, supporting the combined analysis of Table 5.

\section{CONCLUSIONS}

Despite their unique oil-boom context, the findings in Table 5 resemble results from other social demographic studies of migration. Our indicators for students' educational and occupational aspirations predict migration intentions in much the same way as adults' educational and occupational achievements predicted migration behavior in other studies. The similarity extends to this detail: occupational effects faded in multivariate analysis, where we controlled for the stronger effects of education (compare with research cited by Ritchey, 1976).

Two unusual variables in our study measured the theoretically important concepts of social ties to location and attitudes towards oil development. Social ties to the islands had the expected effect of lowering the likelihood of leaving, even controlling for background and aspiration variables. Though this conclusion seems obvious, most previous studies have not taken ties directly into account.

It also seems obvious that anti-oil sentiments should affect individuals' thinking about migration, but we found no evidence this is true. In both zero-order and multivariate analysis, island youths' attitudes towards oil had no bearing on their intentions to leave or stay. This negative finding reinforces 
our impression that the predictors of migration intentions among Shetland/Orkney youth are not substantially different than among rural youth elsewhere, despite the other massive (and well plannedfor) changes oil development brought to the islands.

Figure 2 suggests the possibility that oil development had mainly a short-term effect on youth outmigration; survey results appear consistent with this possibility. We do not know how many stayed because of oil development, but we found no evidence that the attractions of leaving, or the type of leaver, are fundamentally different here than elsewhere. In this respect, our data provide little encouragement for the beneficial retention hypothesis.

In two areas, our survey is less complete than we might wish. First, it presents only the "after" picture. If we had had the prescience to conduct a similar survey in 1972, "before" oil, we would now have a much stronger basis for evaluating the impacts of development. It is too late to conduct this ideal study on Shetland/Orkney, so we are trying to do so elsewhere. In 1991 Seyfrit surveyed 1400 students in 13 Newfoundland communities, before the development of the Hibernia oilfield. ${ }^{5}$ We hope to repeat this survey a few years hence, when development is well under way. An additional opportunity may exist in Alaska. In 1992 we plan surveys in the Bristol Bay area and the Northwest Arctic Borough, site of a large zinc mine. ${ }^{6}$ Bristol Bay is a potential site for offshore drilling; if this occurs, our 1992 survey will provide a baseline for subsequent comparison.

Secondly, we surveyed students regarding their migration intentions, but could not follow them long enough to track actual migration. Previous research suggests that intentions do predict migration behavior, and our intentions-based findings agree with those reported in direct behavioral studies. Nonetheless, the research would be strengthened by data on the actual migration of high school graduates. Our Alaska project includes plans to collect such data. Demographic consequences of rapid development remain an important topic for future research, as our resource-hungry civilization looks around for new supplies. 
Table 1. List of Variables (except for attitudes, based on $n=781$ ).

$\underline{\text { Dependent Variable }}$

leaving $\quad 1$ if respondent says he/she is "most likely" to live remainder of life away from Shetland/Orkney Islands (31.4\%), 0 otherwise.

$\underline{\text { Background Variables }}$

shetland $\quad 1$ if living in Shetland Islands (42.8\%), 0 if in Orkney Islands.

age $\quad$ age in years $(13-18$, mean $=15.13, \mathrm{sd}=1.15)$.

female $\quad 1$ if female (55\%), 0 if male.

bornhere $\quad 1$ if born on this island (60\%), 0 if born elsewhere.

longterm $\quad 1$ if either parent lived $>30$ years this island $(49.2 \%), 0$ otherwise.

fathprof $\quad 1$ if father has professional/technical job (22.4\%), 0 otherwise.

$\underline{\text { Aspirations }}$

wantprof $\quad 1$ if want professional/technical job after finishing school (44.9\%), 0 otherwise.

college $\quad 1$ if expect university or higher education college (34.8\%), 0 otherwise.

$\underline{\text { Attitudes }}$

ties ties to islands. Negative of score on the first principal component of items in Table 3 (n $=736$, mean $=0, \mathrm{sd}=1$ ).

antioil anti-oil attitudes. First principal component score of items in Table $4(\mathrm{n}=685$, mean $=$ $0, \mathrm{sd}=1)$. 
Table 2. Crosstabulation of Island by Likely to Leave

\begin{tabular}{|c|c|c|c|}
\hline \multirow[b]{2}{*}{ Islands } & \multicolumn{3}{|c|}{ Likely to Leave Islands } \\
\hline & No & Yes & Total \\
\hline Orkney & $\begin{array}{l}287 \\
64.2 \%\end{array}$ & $\begin{array}{l}160 \\
35.8 \%\end{array}$ & $\begin{array}{l}447 \\
100.0 \%\end{array}$ \\
\hline Shetland & $\begin{array}{l}249 \\
74.6 \%\end{array}$ & $\begin{array}{l}85 \\
25.4 \%\end{array}$ & $\begin{array}{l}334 \\
100.0 \%\end{array}$ \\
\hline \multirow[t]{2}{*}{ total } & 536 & 245 & 781 \\
\hline & $50 p=$ & & \\
\hline
\end{tabular}


Table 3. Ties to Islands Items. Beneath variable names are loadings on the first principal component. Composite variable ties (used in Table 5) is negative of score on this component.

\begin{tabular}{|c|c|}
\hline $\begin{array}{l}\text { comsat } \\
-.74\end{array}$ & $\begin{array}{l}\text { How satisfied are you with living in this community? } \\
\text { (1=completely dissatisfied, } 7=\text { completely satisfied })\end{array}$ \\
\hline $\begin{array}{l}\text { lifesat } \\
-.57\end{array}$ & $\begin{array}{l}\text { How satisfied are you with your life as a whole these days? } \\
\text { (1=completely dissatisfied, } 7=\text { completely satisfied })\end{array}$ \\
\hline \multicolumn{2}{|c|}{$\begin{array}{l}\text { Remaining items coded as } 5 \text {-point scales with low values indicating agreement: from } 1=\text { strongly agree to } \\
5=\text { strongly disagree. This coding polarity is opposite to that of comsat and lifesat above, so loading signs } \\
\text { have reversed meanings. }\end{array}$} \\
\hline $\begin{array}{l}\text { famdisc } \\
.22\end{array}$ & One ought to discuss important plans with his/her family. \\
\hline $\begin{array}{l}\text { famconf } \\
.26\end{array}$ & One should confide more fully in members of his/her family. \\
\hline $\begin{array}{l}\text { home } \\
.52\end{array}$ & Home is the most pleasant place in the world. \\
\hline $\begin{array}{l}\text { famsac } \\
.29\end{array}$ & A person should be willing to sacrifice everything for his/her family \\
\hline $\begin{array}{l}\text { frndshrd } \\
-.45\end{array}$ & Real friends are hard to find in this community. \\
\hline $\begin{array}{l}\text { polite } \\
.49\end{array}$ & Almost everyone is polite and courteous to you. \\
\hline $\begin{array}{l}\text { badname } \\
.55\end{array}$ & People here give you a bad name if you insist on being different. \\
\hline $\begin{array}{l}\text { belong } \\
.70\end{array}$ & I feel very much that I belong here. \\
\hline $\begin{array}{l}\text { critical } \\
-.50\end{array}$ & People are generally critical of others in this community. \\
\hline $\begin{array}{l}\text { peaceful } \\
.37\end{array}$ & The community is very peaceful and orderly. \\
\hline $\begin{array}{l}\text { differ } \\
-.56\end{array}$ & You are out of luck if you happen to be different. \\
\hline $\begin{array}{l}\text { hapislds } \\
.67\end{array}$ & These islands have just about everything that is needed for a happy life \\
\hline
\end{tabular}


Table 4. Attitudes Towards Oil Development Items. Beneath variable names are loadings on the first principal component. Composite variable antioil (used in Table 5) is score on this component.

\begin{tabular}{|c|c|}
\hline \multicolumn{2}{|c|}{$\begin{array}{l}\text { All items coded as } 5 \text {-point scales with low values indicating agreement: from } 1=\text { strongly agree to } \\
5=\text { strongly disagree. }\end{array}$} \\
\hline $\begin{array}{l}\text { oilobj } \\
.50\end{array}$ & People who object to oil development in this area should move someplace else. \\
\hline $\begin{array}{l}\text { natneed } \\
.56\end{array}$ & No one has the right to interfere with the nation's need for oil. \\
\hline $\begin{array}{l}\text { shutdown } \\
-.33\end{array}$ & Industries should be shut down if they fail to meet governmental pollution standards. \\
\hline $\begin{array}{l}\text { clean } \\
-.47\end{array}$ & $\begin{array}{l}\text { As badly as we need new industry and jobs, we can't afford to sacrifice our clean air, } \\
\text { beautiful scenery, and agricultural land to obtain them. }\end{array}$ \\
\hline $\begin{array}{l}\text { employ } \\
.43\end{array}$ & $\begin{array}{l}\text { One person's right to a clean environment isn't as important as another's right to gainful } \\
\text { employment. }\end{array}$ \\
\hline $\begin{array}{l}\text { better } \\
.37\end{array}$ & People in this area are better off than they would be without the oil industry. \\
\hline $\begin{array}{l}\text { waylife } \\
-.37\end{array}$ & The oil industry has had a negative impact on our "way of life." \\
\hline $\begin{array}{l}\text { joboil } \\
.56\end{array}$ & My chances of employment in the islands are better off because of the oil industry. \\
\hline $\begin{array}{l}\text { runout } \\
-.42\end{array}$ & The oil will "run out" before people my age see any benefit from it. \\
\hline $\begin{array}{l}\text { agreemnt } \\
-.21\end{array}$ & $\begin{array}{l}\text { The agreements between the local council and the oil industry have been more favorable } \\
\text { for the oil industry than for the people here. }\end{array}$ \\
\hline $\begin{array}{l}\text { longrun } \\
.70\end{array}$ & $\begin{array}{l}\text { In the long run, I am sure that people in this area will be better off if our oil resources } \\
\text { are developed. }\end{array}$ \\
\hline
\end{tabular}


Table 5. Logit Regression Results: Log Odds of Expecting to Leave (leaving=1) as function of Background Variables, Aspirations, and Attitudes.

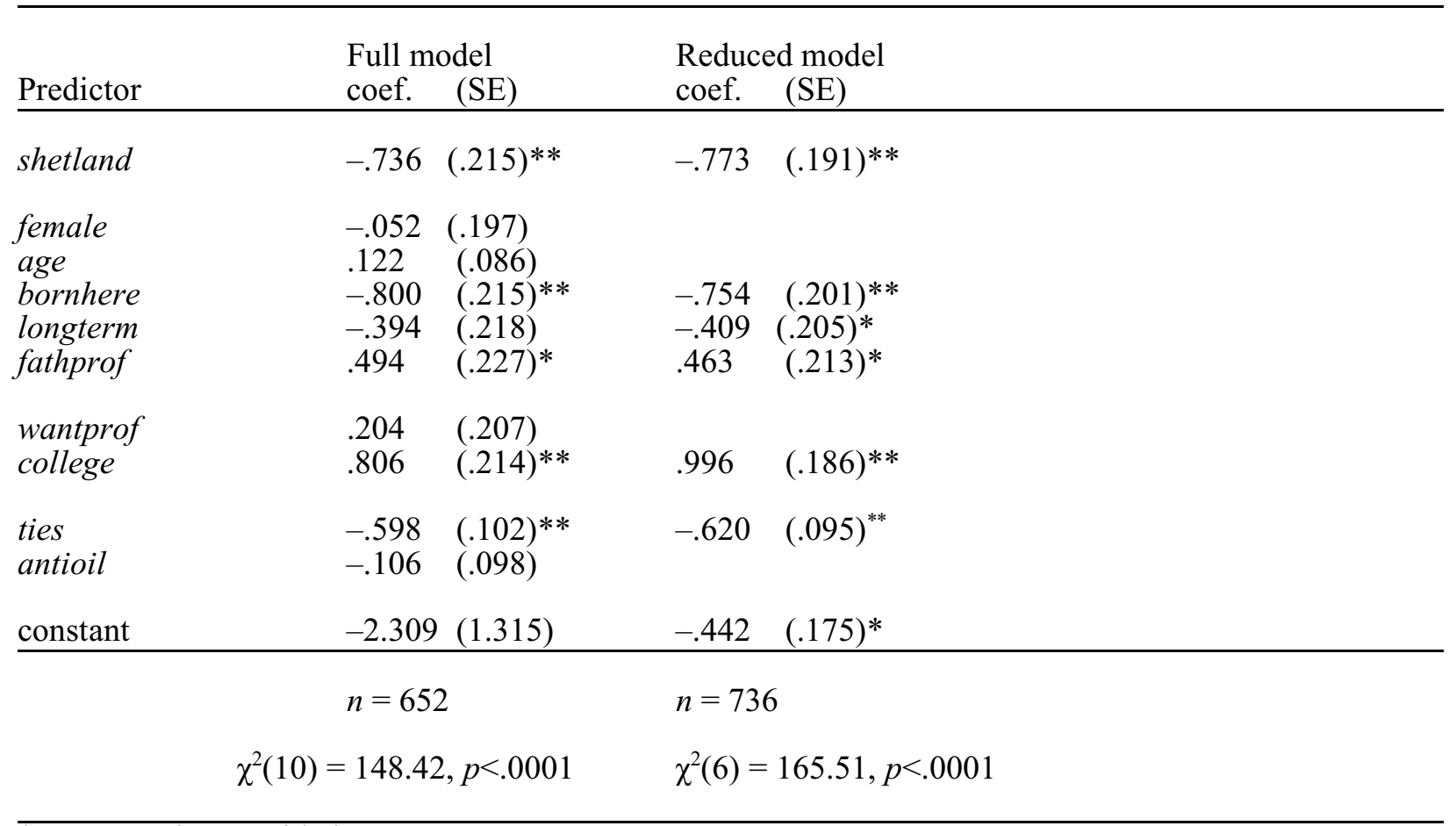

* Asymptotic two-sided $t$ test $p<.05$

** Asymptotic two-sided $t$ test $p<.001$ 


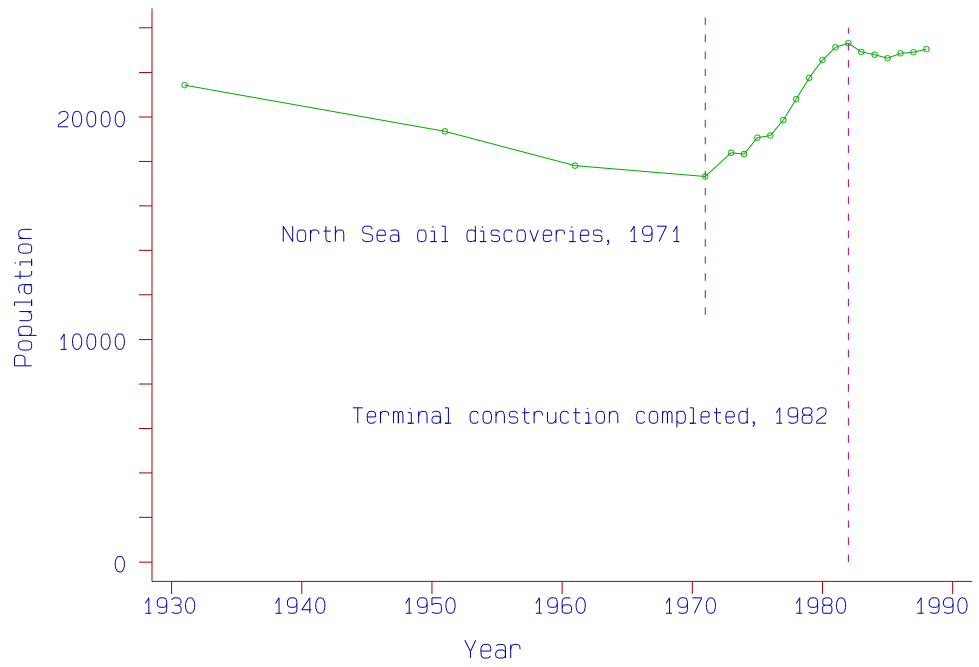

Figure 2: Shetland islands population, 1931-1988.
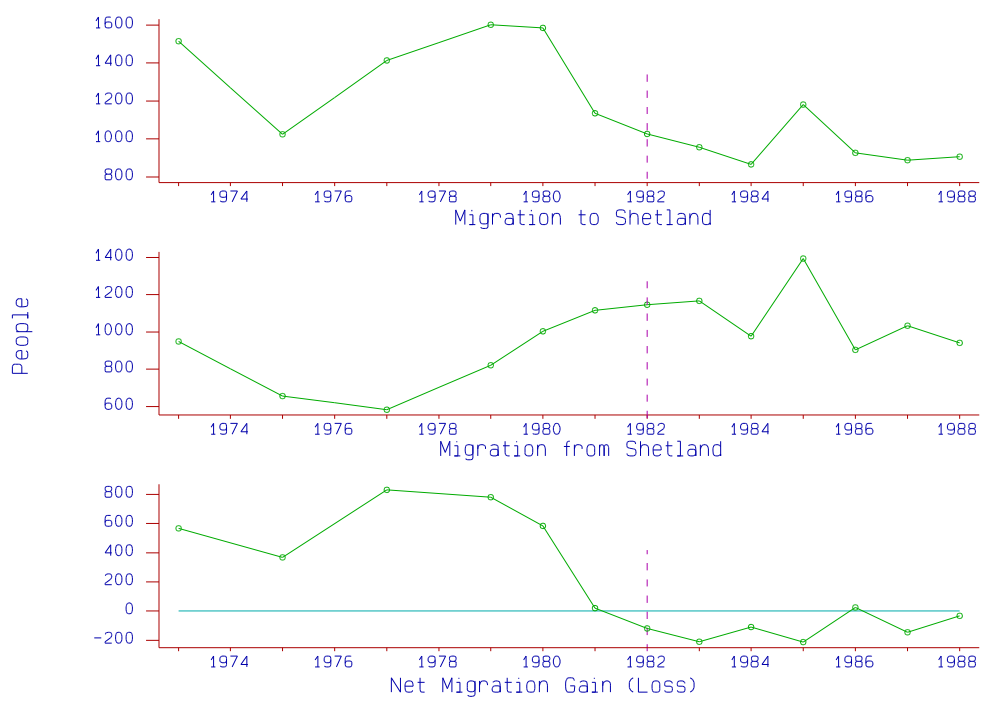

Figure 3: Shetland islands migration, 1973-1988. 


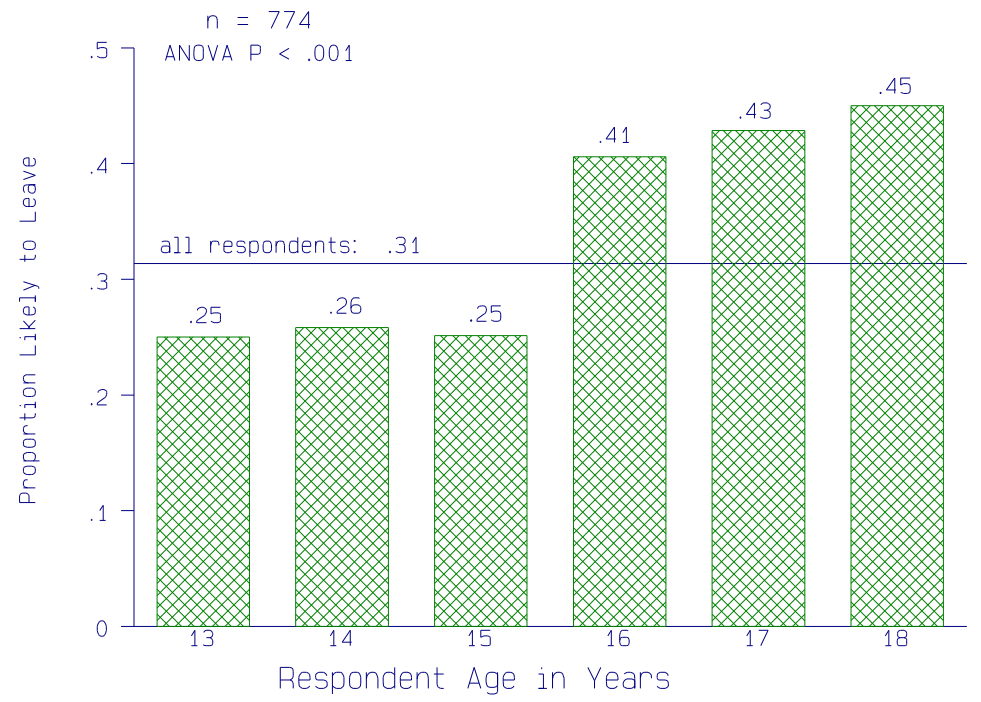

Figure 4: Proportion likely to leave islands, by age.
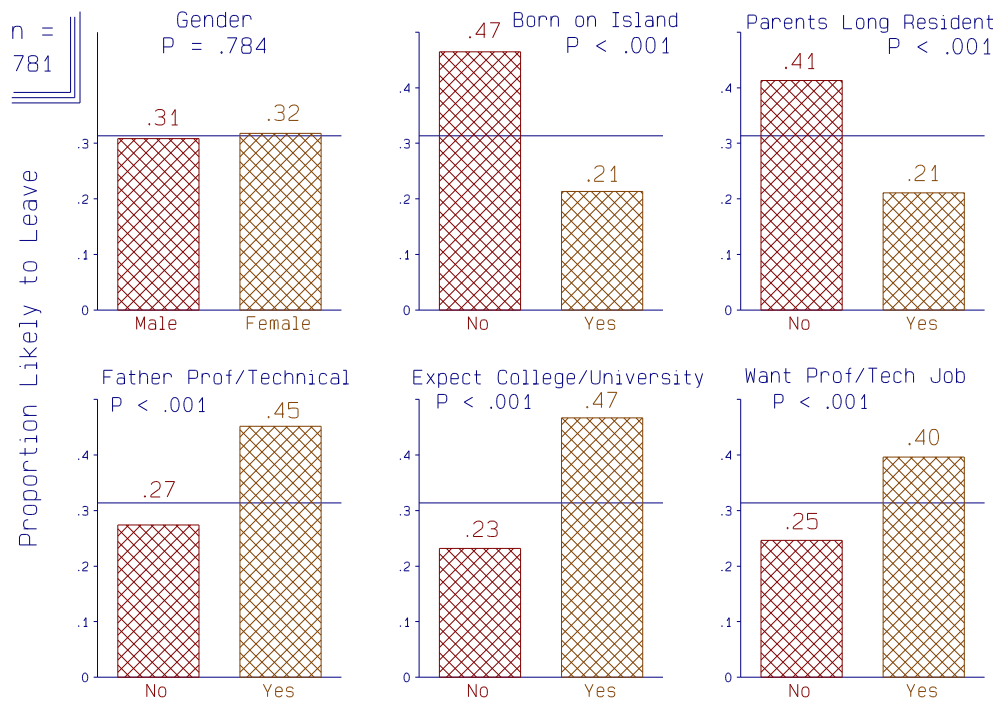

Figure 5: Proportion likely to leave islands, by background and aspirations 


\section{REFERENCES}

Andrews, Wade H. and Ward W. Bauder (1968) The Effects of Industrialization on a Rural County: Comparison of Social Change in Monroe and Noble Counties of Ohio. Wooster: Ohio Agricultural Research and Development Center.

Bohlen, Joe M. and Ray E. Wakeley (1950) "Intentions to migrate and actual migration of rural high school graduates." Rural Sociology 15(4):328-34.

Dixon, Mim (1978) What Happened to Fairbanks? The Effects of the Trans-Alaska Oil Pipeline on the Community of Fairbanks, Alaska. Boulder, CO: Westview Press.

Fishbein, Martin (1978) "Attitudes and behavioral prediction: an overview." Pp. 377-89 in J. M. Yinger and S. J. Cutler (eds.), Major Social Issues: A Multidisciplinary View. New York: Free Press.

Fishbein, Martin and Icek Ajzen (1975) Belief, Attitude, Intention, and Behavior: An Introduction to Theory and Research. Reading, MA: Addison-Wesley.

Freudenburg, William R. (1984) "Boomtown's youth: the differential impacts of rapid community growth on adolescents and adults." American Sociological Review 49(5):697-705.

Goldstein, S. (1976) "Facets of redistribution: research challenges and opportunities." Demography 13(14):423-34.

Gramling, Bob and Sarah Brabant (1986) "Boomtowns and offshore energy impact assessment: the development of a comprehensive model." Sociological Perspectives 29(2):177-201.

Hamilton, Lawrence C. (1992) Regression with Graphics. Pacific Grove, CA: Brooks/Cole.

Heaton, Tim, William B. Clifford and Glenn V. Fuguitt (1981) "Temporal shifts in the determinants of young and elderly migration in nonmetropolitan areas." Social Forces 60(1):41-60.

Hill, Richard J. (1981) "Attitudes and behavior." Pp. 347-77 in Morris Rosenberg and Ralph H. Turner (eds.) Social Psychology: Sociological Perspectives. New York: Basic Books.

Jansen, Clifford J. (1970) Readings in the Sociology of Migration. New York: Pergamon Press.

Kammeyer, Kenneth C. W. (1975) Population Studies: Selected Essays and Research. Second edition. Chicago: Rand McNally.

Lansing, J. B. and E. Mueller (1967) The Geographic Mobility of Labor. Ann Arbor, MI: Survey Research Center.

Lee, Everett S. (1966) "A theory of migration." Demography 3(1):47-57.

Mangalam, J. J. and Harry K. Schwarzweller (1970) "Some theoretical guidelines toward a sociology of migration." International Migration Review 4(2):5-20.

Moira and Moira (1973) Orkney, Review of Development Plan, Interim Strategy. Edinburgh: Moira and Moira (Architects and Planning Consultants).

Morrison, Peter A. (1975) "Population movements and the shape of urban growth: implications for public policy." Pp. 221-43 in John Friedman and William Alonso (eds.) Regional Policy: Readings in Theory and Applications. Cambridge, MA: MIT Press. 
Orkney County Council (1974) Orkney County Council Act 1974. London: Her Majesty's Stationary Office.

Ritchey, P. Neal (1976) "Explanations of migration." Pp. 363-404 in Alex Inkeles, James Coleman, and Neil Smelser (eds.), Annual Review of Sociology, Vol. 2. Palo Alto, CA: Annual Reviews.

Seyfrit, Carole L. (1986) "Migration intentions of rural youth: testing an assumed benefit of rapid growth." Rural Sociology 51:119-211.

Seyfrit, Carole L. (1989) "North Sea oil and Scotland's youth: Shetlander and Orcadian High School students' attitudes toward community, family, and the oil industry." Paper presented at annual meeting of American Sociological Association, San Francisco.

Seyfrit, Carole, M. Melissa James and Donald L. Patterson (1989) "Community responses to resource development: production versus employment." Paper presented at the annual meeting of the Mid-South Sociological Association, Baton Rouge.

Seyfrit, Carole L. and Donald L. Patterson (1990a) "Social impact of North Sea oil development on rural youth: Migration expectations and aspirations." Paper presented at annual meeting of American Sociological Association, Washington DC.

Seyfrit, Carole and Donald L. Patterson (1990b) "Environmental attitudes: youth and oil development in the northern islands of Scotland." Paper presented at the annual meeting of the Southern Sociological Society, Louisville.

Shetland Islands Council (1989) Shetland in Statistics. Lerwick: Research and Development Department, Shetland Islands Council.

Shuman, Howard and Michael P. Johnson (1976) "Attitudes and behavior." Pp. 161-207 in Alex Inkeles, James Coleman, and Neil Smelser (eds.), Annual Review of Sociology, Vol. 2. Palo Alto, CA: Annual Reviews.

Zetland County Council (1973) Interim County Development Plan. Lerwick: Shetland County Council.

Zetland County Council (1974) Zetland County Council Act 1974. London: Her Majesty's Stationary Office. 


\section{NOTES}

1. As discussed later, an ideal but unavailable comparison would be with Shetland and Orkney before development.

2. Forms S3-S6 are roughly equivalent to U.S. 9th-12th grades. Only students attending school on the main islands (Shetland Mainland and Orkney Mainland) were surveyed. About 21\% of the respondents were from more remote communities, but living in hostels in Kirkwall, Orkney or Lerwick, Shetland during school terms.

3. Factor analysis finds weak evidence of several underlying dimensions (such as "family", "peer group"). But up to three factor or component scores, with either orthogonal or oblique rotation, offer no improvement over a single component score in predicting leaving (Table 5). Since they add complexity but lead to substantially the same conclusions, the multiple-dimension results are left out of this paper. Similar observations apply to the oil attitudes items of Table 4: there too, multiple dimensions might be claimed, but are not worthwhile.

4. Throughout our statistical analyses, we employed diagnostic graphs to check for outliers, influential cases, or other distributional problems. For example, the logit regressions of Table 5 were criticized using techniques described in Hamilton (1992). We found no serious problems.

5. Supported by a grant from the Institute of Social and Economic Research, Memorial University of Newfoundland.

6. Supported by a grant from the National Science Foundation. 